\title{
INCALCULABLE, UNACCOUNTABLE, INDIVISIBLE? WALT WHITMAN'S LESSONS IN ARITHMETIC
}

\section{STEFAN SCHÖBERLEIN}

I heartily advise you to peg away at the arithmetic-do something at it every day-arithmetic is the foundation of all such things - (just as a good stone wall is the foundation for a house) become a good arithmetician first of all-

-Whitman to Pete Doyle ${ }^{1}$

As SURPRISING as it might seem to some, Walt Whitman was once a math teacher. The proto-hippie with his flowing beard and saggy pants, so proudly singing of infinites and things beyond measure, at one point stood in front of a crowded roomful of students in a stuffy Long Island schoolhouse and discussed multiplication tables, long division and subtraction rules. And he was passionate about it, too $^{2}$ - a passion he carried forward into Leaves of Grass and inscribed into virtually every page of his poetic corpus.

Over the course of Whitman's poetic life, arithmetic in Leaves did not remain a static symbol but changed alongside the poet's project. Embraced for its radical language of equality, the science of addition, subtraction, multiplication, and division quickly became a metaphoric staple in Whitman's poetic assembling and disassembling of nature into temporary aggregates and complex particulars. Still, with the dawning of the Civil War, Whitman observed the mathematical principles he employed as a lyrical elevation of life, turn into a practical devaluation of it - a turning into numbers of bodies, that could then easily be calculated away as long as the overall equation was favorable. What Whitman the educator embraced and Whitman the "rough" celebrated, the "Good Grey Poet" schooled by fratricidal conflict had to reign back in. The following pages will follow this development from early traces of mathematical thought in Whitman to its inception as a poetic-political program in the 1855 edition of Leaves of Grass and 
its subsequent reevaluation in the context of the Civil War.

While grounded in a historical reading of Whitman's text, this essay then also echoes and corresponds to an emerging critical discourse on the intersections of art and mathematics ${ }^{3}$ - especially in German media theory following the publication of Friedrich Kittler's post-structuralist magnum opus Musik und Mathematik, which media-archeologically tries to rethink the epistemological walls that today separate letter, sound, and number. While Kittler himself dives deep into a Homeric past to stake his claims, the nineteenth century - and especially Whitman's democratic epic — seem like a prime entry point to considering these seemingly divergent scribal and logical systems together. Growing out of a soil saturated with New England's transcendental idealism, the mid-1800s saw number and letter suddenly rediscovering their kinship. "Calculations are works of taste in the same manner as the productions in music and poetry," for instance a 1840s article in a musical journal states, "though it may be also true that they are more often applied than music or poetry to what are commonly called useful purposes." Whitman, all about "useful" poetry, would take up the challenge suggested by such a claim and (re)construct a rigorous arithmetic in and out of language that even by today's standard has lost little of its radicalism. And it all began with Whitman's own, hands-on experience with mathematics: in school.

\section{Arithmetic of Youth}

While Walter Whitman's time as a small-town schoolteacher (18361841) was by any stretch of the imagination just a temporary solution to help the ambitious young man through a financial rough patch, he did apparently show an honest interest in the well-being of his pupils as well as employ some rather unorthodox teaching methods-one of them being the daily practice of mental arithmetic. In those days, as Bernstein Freedman observes, this practice was "evidently a procedure strange enough to warrant special comment" when Whitman's former students were interviewed by Whitman' disciples (in this case Horace Traubel) many years later (Freedman 29). 
In this regard, Whitman seems at least partially indebted to the set of educational practices he had experienced as a student himself. ${ }^{5}$ Whitman's own teacher had apparently adhered closely to a so-called Lancasterian view of education-a Quaker-inspired school-reform movement that instituted student "monitors" to teach younger students as a central pillar of its praxis. While this somewhat student-centered approach (anticipating later peer-tutoring strategies) relied heavily on rote repetition in some subjects, it did emphasize understanding and not memorization as a main principle for mathematic instruction. For instance, the Manual that guided both Whitman's teacher as well as Whitman's teaching (it remained the official rulebook for the New York region until the mid-1800s) ${ }^{6}$ proposed many educational goals and methods that are still fundamental to math instruction today: understanding the relationship between numbers and objects, deemphasizing mere counting, focusing on hands-on work with geometrical models, and respecting individual as well as collaborative work and the need for frequent practice of mental arithmetic (AManual of the System 28-29). Young Whitman would have encountered such mathematics as a means to solve problems and as a tool that could potentially be applied to the real world - unlike many of his peers, who would still be expected to learn primarily by obediently copying already solved exercises from the teacher's blackboard into their "ciphering book." It is no wonder, then, that the approach to math undoubtedly shaped by this experience was one of the things Whitman's own students would remember.

Even afterhis time as a teacher, the now-journalist Walter Whitman remained interested in education in general - and in the instruction of arithmetic in particular. Following his literary plea for a "more philosophical system" of education in "Death in the Schoolroom," the young writer visited a number of local schools to observe their teaching methods and comment on their value to the American public. From 1841 to at least 1848, institutional records and Whitman's own journalism indicate numerous visits to local schools - arithmetic being the prime lesson of choice for Whitman's observations. ${ }^{9}$ What makes for good instruction in mathematics is not "ciphering through the book" 10 as an exercise of rote repetition, Whitman subsequently notes, but the 
student's ability to transfer his/her knowledge into the 'real world':

To put [a student] through the arithmetic is not much; to make him able to compare, calculate, and quickly seize the bearings of a practical figure-question such as occurs in business every hour, is a good deal. (Cited in Freedman 162)

Whitman even goes as far as recommending particular mathematics textbooks. In the review-section of the Brooklyn Daily Eagle of December 21, 1846, for example, we find him "conscientiously recommend[ing] the Practical Arithmetic, prepared by James B. Thompson [sic]," which he urges to be used in every Brooklyn school (Freedman 152-153). Like Whitman taking a stance against "ciphering," Thomson's work ${ }^{11}$ not only underscored the future poet's call for practical (and business-oriented) education in arithmetic, but also aimed to train each reader's "mind" and foster a true understanding of mathematical principles. ${ }^{12}$

What is contained in the main body of the textbook is still much more than a mere set of practically oriented math exercises-it is a representation of the United States in numbers, a civics lesson in arithmetic. Every other page of Thomson's text is charged with the language of patriotism, and even a fleeting glance from the journalist Whitman would have revealed an abundance of the phrase "United States" throughout the book. From simple questions about "how much time had elapsed" since the "Independence of the United States was declared"13 to short excerpts of federal law or Supreme Court rulings and even history lessons about the genesis of federal currency (Thomson 165-166, 259, 227, 188), Thomson's work draws a deeply rational, mercantile picture of public life in the United States. Students of Thomson are not just meant to understand how math works but how a society like the U.S. functions - a society that appears so fundamentally based on the mathematical principles behind its taxation systems, interest rates, and stock exchanges. Learning math here means becoming an enlightened citizen. In arithmetic, Thomson seems to suggest, lies the key to participation in the American Republic and its system of market capitalism.

Why this work would have appealed to the American bard who 
would soon set out to provide a "strict account of all" (Leaves of Grass $68)^{14}$ in sprawling verse, seems clear. And while mathematics was to be only one of the many sciences Walt Whitman would put in their place in Leaves of Grass, it is certainly no exaggeration to claim that it was indeed central to its genesis - quite literally. Setting the precedent for later renditions of Leaves, the poet's hands-on approach to printing the oddly oversized 1855 edition relied heavily on what Ed Folsom calls "Whitman's arithmetic."15 Attempting, for instance, to figure out a page-count for his upcoming publication, Whitman sketched out careful calculations on a piece of notepaper using the word-averages of his own densely scribbled manuscript pages and an edition of Shakespeare's poems as signposts - and employing addition, long multiplication, and long division in a rather sophisticated manner for somebody whose own schooling ended at age 11 (see Figure 1). ${ }^{16}$ What we see in these exercises is Whitman turning his words into numbers, his pages into averages, and his book project into a monetary calculation. If mathematics can make one understand the American system, as Thomson's book suggested, it seems only logical that Whitman's "grand American expression" (xi) would be generated from the same spirit of thrifty arithmetic.

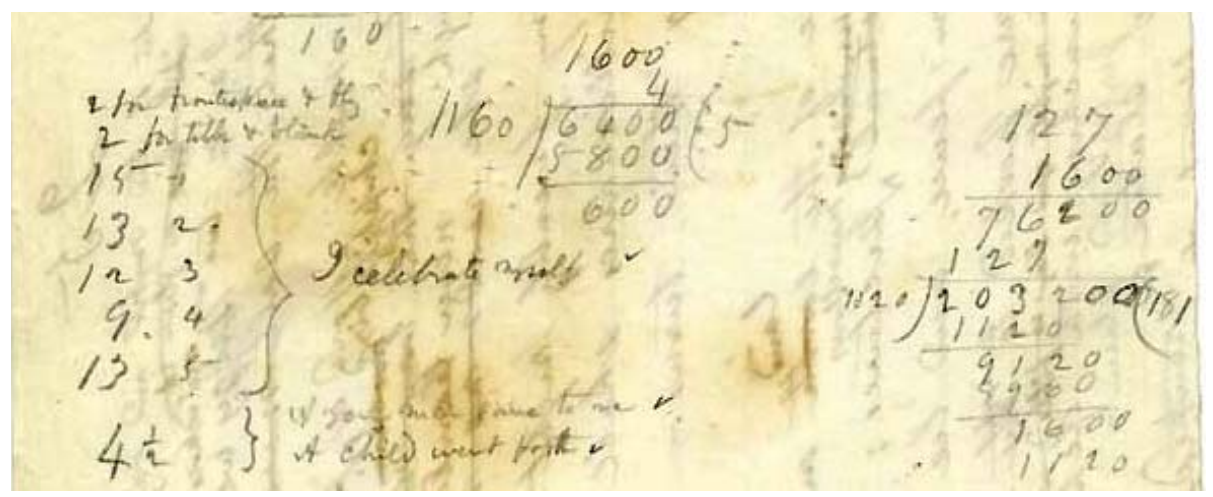

Figure 1. Whitman's Arithmetic (University of Texas Humanities Research Center).

In planning out Leaves for print, Whitman was hence struggling with a very "practical figure-question" of his own. A problem that he failed to solve quite productively: only a miscalculation in adding up 
page numbers freed up enough space for the poet to then hastily insert introductory prose to avoid blank pages (Folsom, "The Census" 73). When Folsom consequently argues that this edition shows "arrangement based on spatial concerns rather than on thematic ones ("The Census" 76), he also reminds us of the crucial impact that Whitman's own mathematical abilities (and shortcomings) had on the creation of this Urtext of American poetry. Without long division, we might not have a Leaves of Grass as iconic as the 1855 edition - and with a bit more of Whitman's attention focused on his calculations, we certainly would not have its preface.

\section{Arithmetic of Democracy}

That Leaves of Grass itself is brimming with the language of arithmetic is certainly a well-known - though rarely commented on-fact. From Whitman's frequent use of "average" (both as verb and noun) to terms like "add," "divide" or "multiple," the 1855 edition seems to base both its argument and its language in parts on this most fundamental of the branches of mathematics. Wherever we find ourselves in Leaves, a mathematical idea, metaphor or expression is only a stone's throw away: from "sum" (iii, x, 60), "equal(s)" (v, vii, 14, etc.), "number" (vii, viii, 40, etc.), "multiplication table" (ix), "infinitesimal" (x), "divide(s)" (x, xii), and "subtract" (x) to "thousand(s)" (xi, 14, 24, etc.), "difference" $(25,67)$, "calculated" (26), "unequal" (31), "infinite" (35), "multiples" (43), "fraction" (43), "trillions" (49), "multiplied" (51), "count" (51), "ten thousand" (54) and "value" (59, 60), even a fleeting glance across the poet's pages reveal them to be saturated with mathematical terms. "Whitman's arithmetical language is remarkably consistent," Sholom J. Kahn has rightly observed, ${ }^{17}$ and scholarship from the field of mathematics itself seems to suggest an underlying numerical logic behind the poet's verse..$^{18}$ Even a fleeting glance at some of the central moments of Leaves underscores the importance of basic arithmetical ideas to its democratic impulse.

"I bring not money or amours or dress or eating," Whitman writes in what would later be titled "A Song for Occupations," "but I bring as good; / And send no agent or medium . . . . and offer no 
representative of value - but offer the value itself" (59). ${ }^{19}$ Whitman proclaims his poems will look beyond appearances-but instead of finding souls, ideas or sprit underneath it all, the poet discovers value. Like the mathematical textbooks of his time (including Thomson's), Whitman's poetics carefully distinguish between "worth" and "value"- the former connoting an appraisal or judgment, the latter being purely numerical. ${ }^{20}$ In a twist on Emerson's famous claim in "Nature" that a "natural fact" is a mere "symbol of some spiritual fact," Whitman briefly acknowledges a difference between appearance (worth) and essence (value), only to subvert it in the notion that such an arithmetical "value" cannot function as an a priori. While mathematically the value of " $1+1$ " is " 2 ," this particular addition is not " 2 " in essence and we just happen to find it expressed as such. " $1+1$ " is not a mirage but merely a different way to state " 2 "- and " 2 " can at the same time be a part of other calculations. Even vast concepts such as time and space are then just compounds of a "few quadrillions of eras" and "a few octillions of cubic leagues:" "They are but parts .... any thing is but a part" (51).

"The idea of the world as a text or formula which theoretically could be deciphered," Imogen Forbes-MacPhail argues, "often translates into an ambition to incarnate language or mathematics into reality itself through providing a 'uniting link' between the material and symbolic worlds." ${ }^{21}$ While, indeed, Whitman uses mathematics to "incarnate" his poetics, he nonetheless never sees it as a stepping-stone to finding a "Divine Logos" behind it all (as Forbes-MacPhail observes of other nineteenth-century authors). The spiritual and the material are one in Whitman, and arithmetic is the language that allows him to make this claim. Whitman seems to suggest, that the beauty of math is that it can be manipulated, manhandled, and broken down. It is a wrestling with the material world. The poet of Leaves appears therefore more in line with later thinkers like John Dewey, who, writing about mathematics instruction a few decades later, would state:

Mathematics is said to have . . cultural value in its enlargement of the imagination in dealing with the most general relations of things; even religious value in its concept of the infinite and allied ideas. But clearly mathematics does not accomplish such results because it is endowed with miraculous potencies called 
values; it has these values if and when it accomplishes these results, and not otherwise (emphases mine). ${ }^{22}$

Playing with the mathematical and cultural meanings of value (i.e. "worth"), Dewey advocates what any good teacher of arithmetic should: the creation of meaning from mathematical constructs; the gleaning of worth from value. Whitman, once a school-teacher and now a self-proclaimed teacher of democracy, did just that.

By offering "value itself," Whitman not only updates transcendental idealism through mathematical metaphor, but also opens it up to a new line of poetic inquiry. Essence and appearance in Leaves are interconnected to such a degree that their boundaries blur. The facts of everyday life - the busy streets, a cocked hat, the runaway slave-suddenly do not merely point to the spiritual meaning lurking behind it all, but seem to define, perhaps even physically constitute, such meaning. In comprehending every object, fact, and living being as simultaneously a mathematical complex (" $1+1$ ") as well as a value ("2"), Whitman ascribes "worth" to both-equal worth. While Emerson relies on allegories to plead for transcendence, the poet of Leaves sets out to demonstrate his more materialist thesis. Mathematical value, after all, can be proven.

Thomson's arithmetic textbook had already informed Whitman of one of the fundamental ideas involved in such calculations: "The equality between two numbers, or sets of numbers, is expressed by . . . the sign of equality" (27), Indeed, if Whitman's and Thomson's books share a single feature, it is their propensity for the word "equal." Browsing through the 1855 Leaves, we see a number of verbalized mathematical equations drawn up by Whitman that emphasize with calculated precision an understanding of equal value that has little patience for qualifying remarks. As much as " 5 plus 3 is equal to eight" (Thomson 27), Whitman casts "unknown heroes equal to the greatest heroes" (25) and speaks of things "equally divine" (44) or "equally perfect" (34). Instead of more abstract notions of "equality"religio-political ideals that in 1855 could still be employed to uphold class difference, slavery, as well as the disenfranchisement of women and children ${ }^{23}$ - Whitman's arithmetic of value is a materialistic twist 
on an idealistic concept. Instead of an abstract equality of enlightened minds or a brotherhood of souls, Whitman's scandalized readers find that here body equals soul, sex equals piety, and sweaty armpits equal prayer. The whole of Leaves hinges on the term "equal," which seems to eternally connote a fundamental sameness in value even between disparately appearing elements: "ten" is equal to " $3+7$ " and " 42 " is equal to " 16 " in the very same sense that "president" equals "prostitute" in Whitman's opus.

In an American context, as scholar of philosophy Judith M. Green rightly observes, there are "two very different concepts of equality, one being a mathematical concept meaning identity, sameness, and interchangeability, and the other being a social and metaphysical concept meaning commensurability in value of importantly differing, non-interchangeable persons."24 Arguably, the 1855 Leaves heavily relies on the former as an important corrective to the latter. In Whitman's prose, democratic "commensurability" must constantly be challenged by "sameness" as well as "interchangeability" on a very fundamental, numerical level so as not to slip into a praxis that looks more like an aristocratism generated from constitutive differences in class, gender, or race.

Whitman's catalogues fulfill this work, offering proto-behaviorist sketches of people not cast as complex psyches characterized by individual 'non-interchangeability' but as figures defined by what they do:

The pure contralto sings in the organloft,

The carpenter dresses his plank .... the tongue of his foreplane whistles its wild ascending lisp,

The married and unmarried children ride home to their thanksgiving dinner,

The pilot seizes the king-pin, he heaves down with a strong arm,

The mate stands braced in the whaleboat, lance and harpoon are ready,

The duck-shooter walks by silent and cautious stretches,

The deacons are ordained with crossed hands at the altar,

The spinning-girl retreats and advances to the hum of the big wheel,

The farmer stops by the bars of a Sunday and looks at the oats and rye. . . (21)

Folsom channels Whitman's view of these catalogs, by having the poet ask: "What's the activity that defines this person? If I were doing that 
activity, that person would be me. ${ }^{.25}$ By focusing on actions and not identity, Whitman underscores a sense of an egalitarian "en masse" (28) that has little room for fundamental, individual difference when it comes to defining equality - a concept more radical in Whitman's poetics than the contemporary "social and metaphysical concept" of the term would have allowed. From the metropolitan sprawl of the urban masses to farmers, slaves, and Natives in the countryside, differences in occupation, status, or phenotype never quite rise to the level of defining personhood in Leaves; rather, it is defined by actions or, perhaps better, roles. As such, these merely add flavor to a democratic, materialist experience of fundamental sameness. Instead of unique individuals, Whitman's 1855 Leaves presents mathematical operators-positions without essence to be filled by bodies of perfectly equal value. Interchangeability, in Whitman, is the true thrill of embodied, conscious life - and not a denigration of it.

Throughout the 1855 edition, Whitman returns to this mathematical notion of "equality" as a medium to express the American experience he observes. Marching up long catalogs of figures to meet the full force of his arithmetical verse, Whitman almost naturally guides the reader to equate them: in his catalogs, line equals line, and each depicted person is equal to the next in the poet's vision. Like a democratic long multiplication or addition in columns, these catalogs are not structured hierarchically but follow the mathematical logic of equation: instead of periods, these catalogs have commas, and in place of rhyme and meter, one finds free verse. Frequently relying on syntactical equivalents of " $=$ " (i.e. conjunctions like "as much as" or "and" as well as parallelisms or epanalepsis), Whitman's "strict account of all" (68) literally becomes a balancing act, his calculations never stopping before an understanding of equal value is achieved.

For instance, in the poem ultimately titled "The Sleepers":

The Asiatic and African are hand in hand .... the European and American are hand in hand,

Learned and unlearned are hand in hand . . and male and female are hand in hand; (76) 
In its repetition, "are hand in hand" becomes almost entirely meaningless, the sole purpose of the phrase now no longer that of a carrier of information but as a simple sign of equating. In the careful balancing act of Whitman's lines, readers see the notion of sameness and interchangeability that the poem argues for. Applying the structure " $1+1=2$ " to a variety of figures, we are left with the almost banal insight that each instance of " 1 " expressed as a bodily figure by Whitman cannot be distinguished from the other. They are interchangeable and of perfectly equal value.
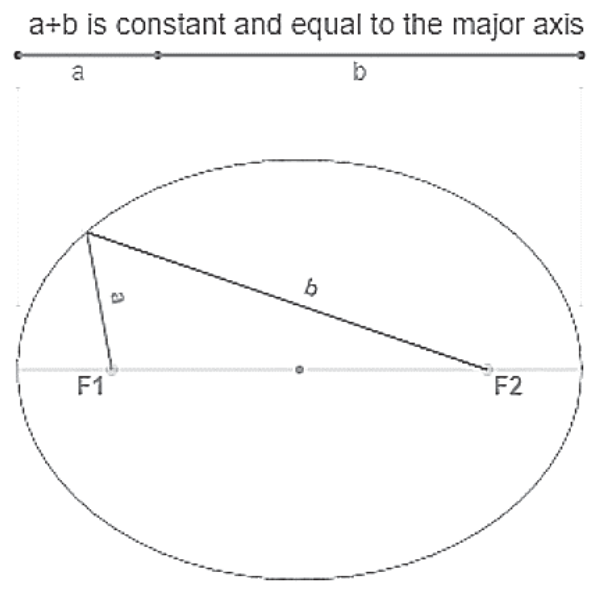

Figure 2. Ellipsis (www.mathopenref.com/ellipse.html).

Whitman's use of ellipses here is striking as well, given the mathematical connotations of this grammatical device. A wonderfully poetic, geometrical expression of the arithmetical principle of "equality," the term "ellipsis" describes a figure made up by "the set of all points in a plane the sum of whose distances from two fixed points is constant" (Figure 2). ${ }^{26}$ Through the eye of mathematical ellipsis, Whitman's line creates a "sameness" within a seemingly two-dimensional problem. Instead of hierarchy, we find a universal constant that renders all perception of hierarchy mute. If " $a$ " in figure 2 is the "Asian" and " $b$ " the "African," then they are equal to every other expression of $a+b$ (say: "the European and American") when rendered through the figure of the ellipses. More than just a clever way to avoid the unseemly grapheme 
of the "symbol of equality" in a literary text, then, Whitman's ellipsis is a way of imaging even the most disparate of positions as radically equal when compared to the "major axis" of embodied, temporal existence.

In Leaves, this notion of equality drives all attempts at counting, subtracting, dividing, and measuring so rampant in Whitman's lines. "The sum of all known value and respect I add up in you whoever you are" (60), the poet proposes at one point, only to find himself ultimately lacking numbers to account for the sheer vastness of existence. Whitman's calculations of equality can only stop at infinity, as he had already informed his readers in his preface:

To add or subtract or divide is in vain. Little or big, learned or unlearned, white or black, legal or illegal, sick or well, from the first inspiration down the windpipe to the last expiration out of it, all that a male or female does that is vigorous and benevolent and clean is so much sure profit to him or her in the unshakable order of the universe and through the whole scope of it forever. (x)

The point of math (much like many other sciences) in Whitman is to find its endpoint, to discover its logical conclusion in plenitude and infinitude in order to tease out the poetic potential in it.

Any attempt to assert a difference in value between persons - beings that, as Whitman has cast them, are each essentially infinite-hence becomes not only a mathematical impracticality but an impossibility. The poet's arithmetic is here seemingly rehearsing Galileo's paradox, a longstanding mathematical truth before Georg Cantor's work questioned it later in the nineteenth century. The paradox boils down to the somewhat commonsensical notion that infinities cannot be compared. ${ }^{27}$ In the arithmetic of Whitman's time, no difference could be asserted between two sets of infinite numbers - they just proclaimed " $\infty$ " while " $<$ " and ">" were rendered invalid mathematical operators. In their mutual incomparability and undifferentiability, sets of infinite value declare an equality beyond measure. Whitman's early sense that arithmetic has to speak to and reflect the real world is still here-but intensified to the extreme. Instead of just explaining a world of commerce, it now illuminates the universe. The poet's calculations in the "average unending procession" of life (43) approach with an arithmetical exact- 
ness the end of measurability. This numerical optimism in Whitman is a constant in earlier editions of Leaves. Or it would be until "infinites" suddenly turned into soldiers and arithmetic into an operation of war.

\section{Arithmetic of War}

The mathematics of war are still very much with us today. On a popular online platform aimed at high school teachers, we can find a highly rated classroom activity titled "Civil War Mathematics Game." description is chilling, even given the one and a half centuries that stand between its inception and the conflict it renders as a "game":

This Civil War Mathematics Activity was created to integrate Social Studies and Mathematics. Each student selects a General from either the Confederate or Union army and progresses through a "choose your own adventure" type game where they make simple calculations based on battles that they fight throughout the simulation. Students must follow directions and move from one battle to the next. ...

Presenting students (grades 7 to 10) with battle results such as "soldiers $(40 \%)$ " and the respective "starting values" (total number of soldiers before battle), the activity has them calculate body counts. Victory or defeat, the exercise suggests, is a numbers game.

While certainly more than a bit macabre, there is a historicity to exercises like these. If we take a glance backwards, we find very similar examples in arithmetic textbooks produced in the Civil War era. Northern as well as Southern schools let its student populations know that practical mathematics now also entailed calculating troop movements, death tolls, and starvation rates:

If a regiment of soldiers contains 1128 men, how many men are there in an army of 106 regiments? ${ }^{29}$

A detachment of 2000 soldiers were supplied with bread sufficient for 12 weeks, allowing each man 14 ounces a day, but finding 105 barrels containing $200 \mathrm{lbs}$. each, wholly spoiled, how many ounces may each man eat daily . . ? ? $^{30}$

The third part of an army was killed, the fourth part taken prisoners, and 1000 fled; how many were in this army? how many killed? how many taken captive? ${ }^{31}$ If one confederate soldier kill [sic] 90 yankees, how many yankees can 10 confederate soldiers kill? ${ }^{32}$ 
What entered Leaves of Grass as a noble metaphor to plead for a fundamental equality in human life had by the 1860 s become a tool for warfare- a fact so obvious in Union and Confederate States that exercises like the above, aimed at young children, apparently needed no further justification.

The Civil War was indeed a war of numbers and logistics, propelled by what Abraham Lincoln termed an "awful arithmetic,"33 and with many battles in the later months decided by sheer numbers alone. Lincoln's secretary (and acquaintance of Whitman) William O. Stoddard, for instance, later remembered the reasoning of the president in the wake of the Confederate Victory in Fredericksburg-where Whitman's brother George was wounded-as follows:

[Lincoln] says that if the same battle were to be fought over again, every day, through a week of days, with the same relative results [as Fredericksburg], the army under Lee would be wiped out to its last man, ... [T] he war would be over, the Confederacy gone, and peace would be won at a smaller cost of life than it will be if the weeks of lost battles must be dragged out through yet another year of camps and marches, and of deaths in hospitals rather than upon the field. No general yet found can face the arithmetic. . . . (178)

Even a defeat, with around twice as many casualties on the Union side, could (with the right arithmetical outlook) be seen as a victory. Soldiers like George Whitman or the men Walt comforted in the hospitals of Washington, D.C., thus became potentially disposable as long as their deaths made sense in the grand scheme of the conflict. What students learned in their mathematics classes and the president calculated with his generals certainly did not come as news to the poet so intimately acquainted with suffering and "deaths in hospitals." The Civil War, as Whitman must have learned all too quickly, was soon driven by a sort of scrupulous utilitarianism that allowed for even massive losses to appear as a worthy strategy to pursue as long as the ratio of friend to foe and the amount of surplus bodies were in one's favor. Division, subtraction, multiplication, and averaging-once calculations employed by Whitman to argue for radically egalitarian politics-were now literalized in battlefield slaughter and a war of attrition. Be it in mass graves or piles of amputated limbs, the human 
body as a minor fraction in much vaster mathematical operations now seems to suggest a darker flipside to Whitman's earlier arithmetical celebration of life.

Besides a move away from the grandiose, expansive "I" of his earlier works, Whitman's wartime poems in Drum-Taps, published shortly after the war and later integrated into Leaves of Grass, also feature a poem struggling with arithmetic directly. So oddly placed amidst depictions of battle scenes, hospital life, and trauma that many seem to forget its genesis in Drum-Taps, "When I heard the learn'd astronomer" (34) features what has often been read as a critique of (or perhaps even attack against) science:

WHEN I heard the learn'd astronomer;

When the proofs, the figures, were ranged in columns before me;

When I was shown the charts and the diagrams, to add, divide, and measure them;

When I, sitting, heard the astronomer, where he lectured with much applause in the lecture-room,

How soon, unaccountable, I became tired and sick; . . .

What sickens the poet here, though, is not the science of astronomy, but that the speaker is forced to calculate. ${ }^{34}$ The basic functions of arithmetic - found throughout Leaves and celebrated loudly therenow seem like a violation, and the prospect of adding, dividing, and measuring induces a physical sense of sickness. Instead of welcoming its abstraction into numbers, the body now revolts. The poet who pronounced himself a universe and proved it (among other things) with arithmetic, is now repulsed by basic mathematical operations and puts himself beyond its grasp: he becomes "unaccountable."

Physically embedded in a Civil War context, the poem leads its reader to hear the military echoes seemingly lurking behind the arithmetic expressions here: "figures" in "columns" suddenly appear as shadowy soldiers, turned into mathematical playthings in the hands of powerful men who move them around as mere numbers on maps and charts-in full ignorance of the sheer unaccountable vastness that each of these figures represent. What Whitman once invited as a thought experiment-to make a "strict account" of each person's value-was 
suddenly a very real practice on the battlefield. The catalogs that Whitman and thousands of families across the country now perused were not the poetic equations of Leaves but battlefield reports and each figure ranged in the sheer endless newspaper columns proclaimed death, illness, or mutilation (see Figure 3).

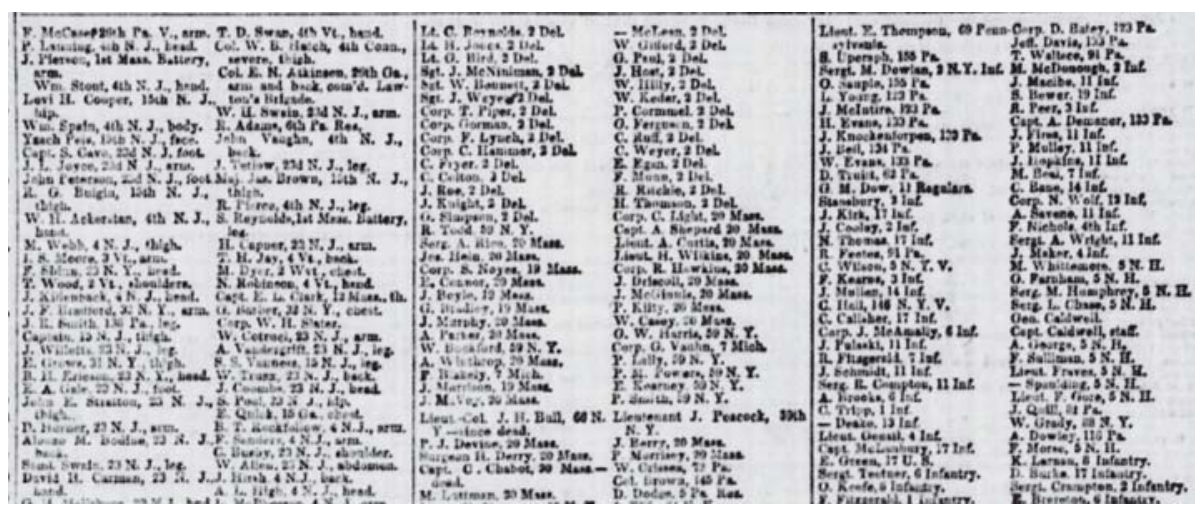

Figure 3. Figures ranged in columns: "List of Casualties" of Fredericksburg in a New York newspaper (detail). ${ }^{35}$

Consequently, when Whitman again attempts to "account" for the masses after the war, it is a startlingly different operation. Instead of a joyous abstraction of human life into the numerical, Whitman's prose-piece "The Million Dead, Too, Summ'd Up"-likely written in the 1860s but first published in 1875-attempts a more literal counting: this time of the Civil War dead. Like a funerary word problem from an arithmetic textbook, Whitman attempts an exercise in addition. Where prior calculations in Whitman approached the infinite, we are here flooded with specific numbers: "25,000 national soldiers kill'd"_-“5,000 drown'd-15,000 inhumed"_-"2,000 graves cover'd"- “3,000 carried away [by water].” As if following the logic of a textbook exercise, the student-reader searches in vain for a prompt to figure out the problem: How many dead per side? What is gained? How many left unburied? But Whitman offers neither question nor answer. His prose just stops short. This is an addition without solution, an accounting of bodies that only unearths more bodies. We have all the addends - the individual bodies to be "summ'd" up — but 
there cannot be a "sum," a word that etymologically suggests higher meanings, essences, and achievements. ${ }^{36}$ Instead, the reader is left with the ultimate lack: the presence of "the infinite dead" all around, a constant reminder of beings no longer there. Whitman's calculation here is nonetheless mathematically sound: he performs an addition of negatives that can only result in a negative. Each subtracted body just equals more absence. Instead of a positive infinite, a vibrant, always expansive multitude, we now approach an infinity of bodies missing, minds silenced, and limbs strewn.

The German satirist Kurt Tucholsky once expressed the cynicism of war by having a French diplomat joke in the wake of World War I: "The death of a single human: that's a tragedy. A hundred thousand dead bodies: that's a statistic!" ${ }^{37}$ Faced with a similar observation as Tucholsky's character, Whitman's arguments for equal value seem to shift from "interchangeability" (mathematical notion of equality) back to "commensurability" (social and metaphysical concept). Whitman's poetic embrace of mathematics as a means to equalize the human experience did not survive the war unscathed. Future editions of Leaves of Grass would be "more Biblical" and refuse to continue Whitman's arguably more radical materialism from earlier editions (though never expunging it). ${ }^{38}$ What Whitman gleaned from the "awful arithmetic" of modern warfare was the danger of dismissing individual identity all too quickly. While his poetic calculations were far removed from allowing for an easy slippage from interchangeability into expandability, Whitman's dividing of the body, his averaging or multiplying of beings and body parts, now seems an eerie foreshadowing of battlefield carnage, and becomes haunted by the metaphoric language both share.

This, of course, does not mean that Whitman abandoned arithmetic outright - but he did find it in need of augmenting, of balancing it out with spiritual metaphors. This is most visible, perhaps, in his later poem "Eidólons" (1881), which would instruct each reader on the first pages of each subsequent edition of Leaves about how to process the poet's arithmetic. A "seer" here cautions the poet-speaker to always include references to "souls" or "essences" (as "eidolons" are variously understood). This "seer" also does not fail to mention 
that this particularly applies to the poet's math: ${ }^{39}$

Of every human life,

(The units gather'd, posted, not a thought, emotion, deed, left out,)

The whole or large or small summ'd, added up,

In its eidolon. ${ }^{40}$

Here we are still adding up complexes (large or small) into values to assess human life, but said life is now individualized into a personhood that finds wholeness and metaphysical worth in an apparently

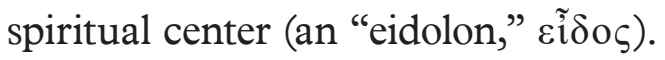

The focus of Whitman's mathematical musings was always to attempt to arrest infinites in the temporary shapes they take-and to begin to comprehend how a single unit in the present is constructed from a vastness beyond measure. Whitman's "eidolon" is not merely a poetic allowance for religious metaphor, though, but also functions as a material indicator: the poem ultimately leaves it up to the reader to decide if it is anchored to a Platonic (idealist) or an Aristotelian (materialist) concept of $\varepsilon \tilde{i} \delta o \varsigma$. Whether a being as $\varepsilon \tilde{i} \delta o \varsigma$ is a mere shadow of its ideal self (Plato) or whether its essence is equal to its physical form (Aristotle), both point to the body as the fundamental index of value and hence the basis of any truly democratic poetics. To elevate the single unit while also celebrating its constituted nature remains the fundamental riddle of Leaves of Grass: Whether one attaches spiritual meaning to an $\varepsilon \tilde{i} \delta o \zeta$ or finds meaning entirely contained in its material make-up, bodies constitute the fundamental building-blocks of Whitman's egalitarian imagination - and have to be treated with a certain awe and respect. With the indexical term "summ'd" in this poem pointing directly back to Whitman's Civil War writings, the joy of arithmetically de- and reassembling life from now on has to at least pay homage to concepts of essence: Instead of adding the "sum of all known value" to plead his case (1855: 60), post-war Whitman now calculates with the "sum of all known reverence" (1881: 172).

When Whitman in his 1870 letter to Pete Doyle compares the importance of arithmetic to that of "a good stone wall [for] the foundation for a house," we can see flickers of all the meanings that mathematics once held in Whitman's work. ${ }^{41}$ In arithmetic, poetry, and 
the construction of a house alike, the poet discovers the deep joy of assembling from basic building blocks with the possibility to re- and disassembly in order to continually re-create something different. To the poet who would ultimately have a small stone house erected for his tomb (and would fuss over every detail of the construction), the thrill of the final product is only deepened by knowledge of its assembled nature. Still, there is a certain natural order to all of these constructions that cannot be entirely disregarded-Lincoln's famous "a house divided against itself cannot stand" applies to the assemblers of words, stones, and numbers. Although differentiating between the values of each building block is futile, each one is still crucial-miss a stone and the wall cannot stand.

If the construct of "America" was to last, it had to have a solid foundation, assembled from its most basic democratic materials: the living, breathing bodies that constitute it physically. Democracy to Whitman exists not only as an ideal to be attained but also as a perfect equation of the material shapes that inhabit it at any given time: The United States - this oddly singular plural — is precisely the units that compose it at any given time. While the beauty of bodies, for Whitman, is their flux through time and space, it is only in their crossing of the threshold of "here" and "now" that their abstract values attain concrete worth. With Whitman's democratic ideal in constant struggle against a praxis scarred by slavery, disenfranchisement, and violent class conflicts, it had to always assert a fundamental sameness in value by radically equating its constituency. The Civil War, however, soon taught the poet that transforming bodies into mathematical operators also opened them up for a more sinister arithmetic: cost-benefit calculations that suddenly added, divided, and measured amputations, deaths, starvation, and disease alongside military supply, popular opinion, and strategic value. This trauma, though, did not cause Whitman to retreat from his arithmetical faith but to rearticulate and make explicit what lay at its core all along. In the perpetual present of the "sign of equality" lies a promise for the future and a culmination of the past as well as a valuation of what is being calculated. The operator " =" channels a complex into a value - and both sides of the equation are of equal worth: 
Beyond thy lectures learn'd professor,

Beyond thy telescope or spectroscope observer keen, beyond all mathematics,

The entities of entities, eidólons.

Unfix'd yet fix'd,

Ever shall be, ever have been and are,

Sweeping the present to the infinite future,

Eidólons, eidólons, eidólons. ${ }^{42}$

The "separate countless free identities" Whitman's seer discovers everywhere as "aggregate and segregate" are here channeled into eidolons that define their position. While mathematics allows access to an essence (the root of "entity"), the eidolon is as a meta-essence of sorts, combining both the temporary fixity of an arithmetical equation as well as the metaphysical unfixity of Whitman's not-yet- and no-longer-physical. The eidolon fills the role of mathematical symbols $(+,-$, $=$ - it is a facilitator of value without having any inherent essence in and of itself.

In Musik und Mathematik, Friedrich Kittler claims that the rigorous infusion of mathematics, and particularly arithmetic, into epistemology forms the basis for our lengthy collective trip from a gematriaic ancient Greece ${ }^{43}$ into a computational future:

We, who write or code, heal or teach, differ from the philosophers: Archytas's thought has been victorious, first with young Dionysios and finally in general. Algorithms and machines run everywhere; we are swimming in their midst. ${ }^{44}$

Archytas, who brought numbers down from the heavens and arrested them in physis, is Kittler's hero of modern mathematics and mechanics. In granting real-world bodies to abstract numerals, Archytas gave birth to scalar music and poetry as well as to modern war: The machineries he constructed from mathematical insights, Kittler gleefully notes, were employed to murder idealistic Archimedes alongside the abstract geometry he stood for. The mathematics that gives rise 
to poetry is also always a mathematics of murder: Whitman's line and the weapon that wounded his brother share a common ancestor. Like Kittler, Whitman seems to sense that, by infusing hitherto sacrosanct bodies and shapes (Platonic geometry) with the radical calculations of (Aristotelian, Post-Archytasian) arithmetic, something striking happens: Nature can now be observed as a vast generative algorithm and manipulated accordingly. Mathematics is then not only a useful tool to calculate the minutiae of everyday commerce nor a mere weapon but something more fundamental: arithmetical poetics seem to allow a glance beyond representation. In calculating a democratic society on paper, one generates it: poetry is an algorithm to be executed, and lines of code are not only assembled from the Real but always beckoning to be released back into it.

It appears only fitting, then, that the term "eidolon" has made its way into the field of computational mathematics - and to math education no less. ${ }^{45}$ Proposed as a means to optimize mathematical computing in an educational context, Kyril Tintarev's "eidola" are envisioned as part of a "natural object interface" which aim to "reif[y]" abstract mathematical ideas in a way that transcends what is possible in the two-dimensional paper-space usually associated with school-mathematics (298). As in Whitman's poetry, "eidola come always at the top of [a computational] hierarchy" and attempt to negotiate between the vast complexity of the physical world and abstract world of mathematics (Tintarev 304). Conceptually, this exercise in object-oriented programming hopes to act as a nexus that channels life into mathematics - and mathematics back into life (as approximated by multimodal visual output). Whitman's early fascination for the "real world" applications of math and his daring poetical exploration into what exactly would (or ought to) be entailed in such operations, seems, in an odd way, to have returned to its origins: in the digital utopia of computing, the idea of reading the world as arithmetic and creating it anew from these very same principles is alive and well. 


\section{NOTES}

I would like to thank Blake Bronson-Bartlett, Ed Folsom, and Arianna Rigon for their comments on my essay.

1 Walt Whitman to Peter Doyle, September [30], [1870]. Available on the Walt Whitman Archive (www.whitmanarchive.org, ID: loc.01534)

2 Much of the information about Whitman's time as a schoolteacher and his views on education here is based on Florence Bernstein Freedman's excellent Walt Whitman Looks at the Schools (New York: King's Crown Press, 1950) and its lengthy addendum-apparatus of Whitman's pre-Leaves writings on this issue. See also Katherine Molinoff's Whitman's Teaching at Smithtown, 1837-1838 (New York: Comet, 1942) and Bernard Hirschhorn's "Views on Education," in: J.R. LeMaster and Donald D. Kummings, eds., Walt Whitman: An Encyclopedia (New York: Garland Publishing, 1998). The latter is available on the Walt Whitman Archive.

3 See, for instance, Jochen Brüning's Die Mathematischen Wurzeln der Kultur. Mathematische Innovationen und ihre Kulturellen Folgen (Paderborn: Fink, 2005); the edited collection Zahlen, Zeichen und Figuren: Mathematische Inspirationen in Kunst und Literatur (Andrea Albrecht, Gesa Von. Essen, and Werner Frick, eds., Berlin: E Gruyter, 2011); Wladimir Velminski's Form. Zahl. Symbol: Leonhard Eulers Strategien der Anschaulichkeit (Berlin: Akademie Verlag, 2012); and Thomas Christian Bächle's Mythos Algorithmus: Die Fabrikation des Computerisierbaren Menschen (Wiesbaden: Springer VS, 2015). Unfortunately, very little of this particular brand of mathematically inclined research in the humanities has been translated into English as of 2016.

4 Robert Henry Bloomfield, "The Mechanics of Music," The Musical World 19 (1844), 294.

5 The Manual of the System of Discipline and Instruction for the Schools of the Public School Society of New-York that guided Whitman as well as his own teacher was written in 1805 and remained in place, largely unchanged, until the middle of the century. See Freedman (18-20) for her account of Walter Whitman's teacher and his close adherence to this manual. Her description of the Lancasterian method, though, remains underdeveloped and ignores its reformist elements almost entirely by casting it as the negative antithesis to Whitman's later views on education - an antithesis that, at least with regards to arithmetic, does not entirely hold up. Like Whitman, Lancasterianism was also strongly opposed to corporal punishment - but nonetheless incorporated a quite strict system of discipline that would undoubtedly have been opposed by Whitman.

6 A Manual of the System of Discipline and Instruction for the Schools of the Public School Society of New-York: Instituted in the Year 1805 (New York: Egbert, Hovey \& King, 1850 [reprint]). 
7 On ciphering books, see also Nerida F. Ellerton, M. A. Clements, and Jeremy Kilpatrick, Rewriting the History of School Mathematics in North America, 16071861: The Central Role of Cyphering Books (New York: Springer, 2012).

8 Walt Whitman, Complete Poetry and Collected Prose, ed. Justin Kaplan, (New York, NY: Literary Classics of the United States, 1982), 1079.

9 When Whitman mentions what classes he observes, more often than not they were indeed arithmetic lessons. See for instance Freedman 33, 53, 110, 170, 258.

10 From an 1846 issue of the Brooklyn Daily Eagle, cited in Freedman 148, 162. This negative sense of arithmetic as "ciphering through" returns in Whitman's later poem "An Old Man's Thought of School" as the embodiment of tedium. Given Whitman's apparent admiration for arithmetic, his use of a different term to talk about poor applications of the science is telling: bad arithmetic is not even worthy of its name.

11 Whitman misspells Thomson's name.

12 James B. Thomson, Practical Arithmetic: Uniting the Inductive with the Synthetic Mode of Instruction. For Schools and Academies (New York: Mark H. Newman, 1846), iiv.

13 A calculation that, as Cohen and Dinin show, Whitman later performed himself in his manuscripts ("Keeping Tally with Meaning: Reading Numerals in Walt Whitman's Manurscripts," Walt Whitman Quarterly Review 34 [Fall 2016], 173).

14 All future citations of Whitman's poetry, unless otherwise noted, reference the 1855 edition: Leaves of Grass (Brooklyn, New York: 1855). Available on the Walt Whitman Archive.

15 Ed Folsom, "The Census of the 1855 Leaves of Grass: A Preliminary Report." WWQR 24 (Fall 2006), 73.

16 Whitman is following the very common "Italian method" (sometimes also called "Austrian method") that is detailed in the Manual that little Walter's teacher apparently relied heavily on and that might have guided Whitman's own teaching (see line 5 of figure 1 and Manual of the System of Discipline and Instruction 14).

17 Sholom J. Kahn, “Whitman's 'Overstaid Fraction’ Again,” Walt Whitman Review 20 (June 1974), 73.

18 See Kathryn Davies Lindsay's tracing of mathematical language in Whitman ("Mathematics: A Clue to Whitman's Philosophy," M.S. Thesis [Southern Connecticut State College, 1965]) as well as Charlotte Downey's (partially underdeveloped) reading of Whitman through set theory, a branch of mathematical logic relying heavily on arithmetic ("How the Mathematical Concepts Portrayed in the Language Patterns of Walt Whitman's and ED's Poems Relate to Meaning," Dickinson Studies 72 [1989], 17-32). Downey, rightly I would argue, proposes that Whitman expresses his "poetic messages in language patterns reflecting mathe- 
matical concepts" (17).

19 Many critics (Adam Bradford, for instance) have picked up on the mercantile connotations of Whitman's verse-especially in Civil War context - but little attention has been paid to the actual mathematical basis to the language of value in Whitman. Hence, a reading like Bradford's concludes that Whitman is combatting a "deflation of human value" (146) with textual commodities that aim to "inspire or recover a sense of human value" (145). What exactly is meant by "value" is left unsaid and we instead find Whitman embracing a sort of sentimental humanism that is at odds with Whitman's earlier poetics and his consistent return to methods of accounting. (See Adam Bradford, "Re-collecting Soldiers: Walt Whitman and the Appreciation of Human Value," WWQR 27 [Winter 2010], 127-152).

20 See for instance Whitman's phrase "taking them all for what they are worth, and not a cent more" (45). We might also compare Thomson's use: "A man bought a hogshead of molasses worth $371 / 2$ cents per gallon" (274) vs. "If any given number is multiplied and the product divided by the same number, its value will not be altered" (89). The latter is abstract, numerical, while the former is representation of the worth of a commodity expressed in monetary terms - a value might be at the core of the hogshead-problem, but it is expressed merely as a "representation of value."

21 Imogen Forbes-MacPhail, "The Enchantress of Numbers and the Magic Noose of Poetry: Literature, Mathematics, and Mysticism in the Nineteenth Century," Fournal of Language, Literature and Culture 60 (2013), 138.

22 John Dewey, Democracy and Education: An Introduction to the Philosophy of Education (New York: Macmillan, 1916), 287.

23 See also Celeste Michelle Condit, and John Louis Lucaites, Crafting Equality: America's Anglo-African Word (Chicago: University of Chicago Press, 1993), 40100.

24 Judith M. Green, "Equality," in American Philosophy: An Encyclopedia, ed. John Lachs and Robert B. Talisse (New York: Routledge, 2008), 242.

25 Walt Whitman, directed by Mark Zwonitzer and Jamila Wignot (PBS DVD, 2008), 21:12.

26 Cynthia Y. Young, Precalculus (Hoboken, NJ: Wiley, 2010), 847.

27 "So far as I see we can only infer that the totality of all numbers is infinite, that the number of squares is infinite, and that the number of their roots is infinite; neither is the number of squares less than the totality of all the numbers, nor the latter greater than the former" (in Stephen W. Hawking, On the Shoulders of Giants: The Great Works of Physics and Astronomy [London: Penguin, 2003], 423). While it is unlikely that Whitman had actually read Galileo (though he did show some familiarity with him later in life), this idea - in its most basic formwould (and probably still does) appear quite logical to many people without deeper 
knowledge of theoretical mathematics. Had he ever read Galileo's work, the poet would have also found the claim that bodies cannot, indeed, be infinite. Cantor and others have since demonstrated that comparisons of infinites are a theoretical possibility.

28 tinyurl.com/tchersgme.

29 Charles Davies, School Arithmetic: Analytical and Practical (New York: A.S. Barnes, 1865), 54.

30 James Shirley Eaton, A Treatise on Arithmetic, Combining Analysis and Synthesis: Adapted to the Best Mode of Instruction in Common Schools and Academies (Boston: Brown, Taggard and Chase, 1861), 159. An almost identical exercise can be found in the 1863 National Arithmetic of Benjamin Greenleaf in its chapter on "Proportions" (The National Arithmetic on the Inductive System: Combining the Analytic and Synthetic Methods: Forming a Complete Course of Higher Arithmetic [Boston: Robert S. Davis \&, 1863], 248). The result is that all of the food supplies for the 2000 soldiers had spoilt. What this would mean to the soldiers is left to the imagination.

31 Roswell Chamberlain Smith, Practical and Mental Arithmetic on a Nerw Plan: In Which Mental Arithmetic Is Combined with the Use of Slate: Containing a Complete System for All Practical Purposes Being in Dollars and Cents (Philadelphia: J.B. Lippincott and Company, 1861), 240.

32 L. Johnson, An Elementary Arithmetic, Designed for Beginners: Embracing the First Principles of the Science (Raleigh, NC: Branson and Farrar, 1864), 39. The book also offered this "Mental Arithmetic": "If one Confederate soldier can whip 7 Yankees, how many soldiers can whip 49 Yankees?" (44).

33 The phrase was ascribed to Lincoln by his secretary William Stoddard. Stoddard (1835-1925), a critic who had praised Leaves of Grass and was likely personally acquainted with Whitman since the late 1850s, might well have discussed with the poet of some of the calculations and debates that surrounded Lincoln's views of the war at the time. See his Inside the White House in War Times (New York: C.L. Webster and Company, 1890), 178

34 Indeed, the whole poem could be read as a defense of romantic science and seems to echo the introductory passages of Alexander von Humboldt's monumental Kosmos that defends an approach to natural science that relies on knowledge and enjoyment of nature and exemplifies it by the figure of the astronomer.

\section{New-York Daily Tribune (December 16, 1862), 1.}

36 The word stems from the Latin summa meaning "the top, summit; chief place, highest rank; main thing, chief point, essence" and is related to the word "super" (etymonline.com).

37 Kurt Tucholsky, Gesammelte Werke. 1925-1928, ed. Mary Gerold-Tucholsky 
and Fritz J. Raddatz (Reinbek Bei Hamburg: Rowolt Verlag, 1972), 192: "Der Tod eines Menschen: das ist eine Katastrophe. Hunderttausend Tote: das ist eine Statistik!" The quote is often misattributed to Joseph Stalin.

38 Ed Folsom, Walt Whitman: Whitman Making Books, Books Making Whitman: A Catalog E Commentary (Iowa City, IA: Obermann Center for Advanced Studies, University of Iowa, 2005). Also available on the Walt Whitman Archive.

39 See also Matt Cohen, "Transgenic Deformation: Literary Translation and the Digital Archive" (Walt Whitman Archive, 2006), www.whitmanarchive.org/ about/articles/anc.00165.html.

40 Leaves of Grass, (Boston: James R. Osgood and Company, 1881), 12. Available on the Walt Whitman Archive.

41 A high praise indeed, given Whitman's frequent linking of the construction of poetry to the production of architecture (see Charles R. Metzger, "Whitman on Architecture," Fournal of the Society of Architectural Historians 16, no. 1 [1957], 25-27).

42 Leaves of Grass 1881, 14 (ellipsis mine).

43 See also Friedrich A. Kittler, "Kabbala: Buchstabe = Zahl," in Baggersee. Frühe Schriften Aus Dem Nachlass, eds. Tania Hron and Sandrina Khaled (Paderborn: Wilhelm Fink, 2015), 77-78.

44 Friedrich A. Kittler, Musik Und Mathematik, Vol. 1. (München: Wilhelm Fink Verlag, 2006), 335.

45 Kyril Tintarev, "Design of User Interface for Computer-aided Instruction of Mathematics," in Mathematics E Mathematics Education: Proceedings of the Third International Palestinian Conference: Bethlehem, August 9-12, 2000, ed. Saber Elaydi (River Edge, NJ: World Scientific, 2002), 290-305. 